\title{
Distribution and Incidence of Some Aphid and Leafhopper Transmitted Viruses Infecting Sugar Beets in Iran
}

\author{
Sh. Farzadfar and R. Pourrahim, Department of Plant Virology, Plant Pests and Diseases Research Institute, P.O. \\ Box 19395-1454, Tehran, Iran; A. R. Golnaraghi, Department of Plant Protection, College of Agriculture and Natu- \\ ral Resources, Science and Research Campus, Islamic Azad University, P.O. Box 14515-775, Tehran, Iran; and \\ A. Ahoonmanesh, Department of Plant Pathology, College of Agriculture, Esfahan University of Technology, Esfa- \\ han, Iran
}

\begin{abstract}
Farzadfar, Sh., Pourrahim, R., Golnaraghi, A. R., and Ahoonmanesh, A. 2006. Distribution and incidence of some aphid and leafhopper transmitted viruses infecting sugar beets in Iran. Plant Dis. 90:252-258.

The main areas for field-grown sugar beet (Beta vulgaris) production in Iran were surveyed to study the occurrence and incidence of Alfalfa mosaic virus (AlMV), Beet curly top virus (BCTV), Beet mosaic virus (BtMV), Beet western yellows virus (BWYV), Beet yellows virus (BYV), Chickpea chlorotic dwarf virus (CpCDV), Cucumber mosaic virus (CMV), and Turnip mosaic virus (TuMV) during the growing season of 2001. A total of 5,292 random leaf samples in addition to 1,294 symptomatic leaves were collected from nine commercial sugar beet growing provinces of Iran and tested by tissue-blot immunoassay (TBIA). Serological diagnoses were confirmed by electron microscopy and host range studies. The highest virus incidence among the surveyed provinces was recorded in Qazvin, followed by Fars, Esfahan, Azarbayejan-e-gharbi, Khorasan, Kermanshah, Semnan, and Hamedan. According to the TBIA results, viruses in decreasing order of incidence in sugar beet were BCTV (27.9\%), followed by BWYV (17.4\%), CpCDV (12.5\%), BYV (10.6\%), BtMV (7.4\%), TuMV (2.9\%), AlMV (1.3\%), and CMV (1.2\%). Nearly $35 \%$ of sugar beets in Iran were infected by one or both of the two leafhoppertransmitted viruses (BCTV and CpCDV). Moreover, about $28 \%$ were infected by at least one of the six aphid-transmitted viruses (AlMV, BWYV, BtMV, BYV, CMV, and TuMV). Overall, one or more of the eight viruses assayed were detected in $45.5 \%$ of the plants surveyed. Several plants (35\%) displaying virus-like symptoms did not react with the virus antisera used, suggesting that more viruses or virus-like agents are infecting sugar beets in Iran. In reference to the earlier reports, this is the first report of AIMV and TuMV in sugar beet fields of Iran. Also, this is the first detection of CpCDV as a pathogen of sugar beet.
\end{abstract}

Additional keywords: beet viruses

A century ago, outbreaks of virus diseases in sugar beet plants (Beta vulgaris L.), with heavy losses, attracted the attention of farmers and agricultural experts worldwide (36). In excess of 100 different viruses and virus strains now have been reported to infect sugar beet under natural or experimental conditions. Some occur worldwide and substantially reduce crop yield and quality $(5,42)$. Beet yellows virus (BYV), for example, is widespread wher-

Corresponding author: Sh. Farzadfar

E-mail: farzadfar2002@yahoo.com

* The $\boldsymbol{e}$-Xtra logo stands for "electronic extra" and indicates that Figure 1 appears in color in the online edition.

Accepted for publication 30 August 2005.

DOI: 10.1094/PD-90-0252

(C) 2006 The American Phytopathological Society ever sugar beet is grown and reduces yield by up to $50 \%(35,36)$. Beet poleroviruses, including Beet mild yellowing virus (BMYV) and Beet chlorosis virus (BChV), also cause sugar beet yield losses ranging from 5 to $40 \%$ (28). In addition, losses associated with curly top disease threatened the viability of the sugar beet industry in the western United States from the 1920s through the 1950s (42).

Sugar beet is one of the major sources of sugar in Iran, where it is grown in autumn and spring. Only a few previous studies on the occurrence of insect-transmissible viruses on sugar beets have been reported in Iran. Beet curly top virus (BCTV) was once observed in Fars $(12,27)$, and also reported from Esfahan province (21). Beet mosaic virus (BtMV) $(15,20,22)$ and $\mathrm{Cu}$ cumber mosaic virus (CMV) $(16,22)$ were found in sugar beet plants showing mosaic diseases. Additionally, BMYV and BYV were recorded from Iran in association with yellowing symptoms $(14,15)$. Sugar beet has suffered from unknown viral diseases in Iran, and such diseases have been considered a possible reason for reduction of cultivation area from 186,017 ha in 1999 to 162,738 ha in $2000(9,10)$.

In the present work, a general survey was conducted to determine the incidence of several insect-vectored viruses, namely, Alfalfa mosaic virus (AlMV), BCTV, BtMV, Beet western yellows virus (BWYV), BYV, Chickpea chlorotic dwarf virus (CpCDV), CMV, and Turnip mosaic virus (TuMV), in nine major sugar beet production provinces of Iran and to determine their relative importance with respect to potential economic losses they may cause.

\section{MATERIALS AND METHODS}

Samplings. During the growing season of 2001,30 to 60 leaves were randomly collected from each of 106 spring-sown sugar beet fields of eight provinces in Iran, including Azarbayejan-e-gharbi, Esfahan, Fars, Hamedan, Kermanshah, Khorasan, Qazvin, and Semnan (Table 1). Within each randomly selected field, sample collection was made by crossing the field in a zigzag pattern in which the distance between two individual samples was 3 to 5 $\mathrm{m}$. The size, stage of crop development, cropping pattern, and crop density were recorded for each field at the time of sampling. Ten to 15 leaves from plants showing typical virus disease symptoms were collected from the same field. In addition, 31 symptomatic leaf samples were collected from a beet field in Ardabil province. Samples were immediately transported in labeled plastic bags over ice in cold boxes to the laboratory and kept at $4^{\circ} \mathrm{C}$ prior to being tested. Virus disease incidence in each randomly chosen field was estimated according to the reactions of leaf sample extracts in diagnostic assays as described below. Disease incidence was also estimated based on symptoms observed in 100 randomly selected sugar beet plants in each field surveyed.

Sources of antisera and positive samples. BtMV (As-0143, PV-0065), BYV 
(As-0185, PV-0406), and TuMV (As-0132, PV-0104) were kindly provided by S. Winter (DSMZ, Braunschweig, Germany), CpCDV-specific polyclonal antibody by $\mathrm{H}$. J. Vetten (DSMZ), CpCDV positive control, CMV, and BWYV raw antisera by $\mathrm{K}$. M. Makkouk (ICARDA, Syria), BCTV antibodies by M. Bahar (College of Agriculture, Esfahan University of Technology, Esfahan, Iran), and the positive control by S. Jalali (Agricultural Research Center, Esfahan, Iran). Our AlMV positive control and raw antiserum were produced against an Iranian isolate of AlMV (26). The positive sample of CMV was kindly provided by V. Alavi (Agricultural Research Center, Sari, Iran). An Iranian isolate of BWYV was used as the positive control (34). The detection systems for BtMV and TuMV were checked for cross-reactivity in the potyvirus group using enzyme-linked immunosorbent assay (ELISA). Crossreactivity between $\mathrm{BCTV}$ and $\mathrm{CpCDV}$ antisera in the geminivirus group was also checked by dot-ELISA.

Tissue-blot immunoassay (TBIA). In this study, TBIA was optimized and used for the detection of sugar beet viruses based on earlier reports (29). Each petiole was cut with a new razor blade in a steady motion to obtain a single plane cut surface and pressed on each membrane (BA-45, Schleicher \& Schuell, Germany). The membrane was washed three times with phosphate buffered saline (PBS) (3 mM $\mathrm{KCl}, 3 \mathrm{mM} \mathrm{NaN}_{3}, 8 \mathrm{mM} \mathrm{Na}_{2} \mathrm{HPO}_{4}, 1 \mathrm{mM}$ $\mathrm{NaH}_{2} \mathrm{PO}_{4}$, and $0.13 \mathrm{M} \mathrm{NaCl}, \mathrm{pH}$ 7.4) containing $0.05 \%$ Tween 20 (PBST) at 5-min intervals, blocked in $1-\mu \mathrm{g} / \mathrm{ml}$ polyvinyl alcohol in PBST, and incubated $30 \mathrm{~min}$ at room temperature (RT). After washing, the membrane was placed in 1:1,000 dilution of IgG-conjugated antibodies in conjugate buffer (2\% polyvinylpyrrolidone-24000, $0.05 \%$ Tween $20,0.2 \%$ bovine serum albumin, and $1 \mathrm{mM} \mathrm{MgCl} 2$ in PBS, $\mathrm{pH}$ 7.4). The membrane was incubated for $1 \mathrm{~h}$ at RT, washed, and directly placed in color development solution ( $0.1 \mathrm{M}$ Tris- $\mathrm{HCl}, \mathrm{pH}$ 9.5 , containing $0.1 \mathrm{M} \mathrm{NaCl}, 5 \mathrm{mM} \mathrm{MgCl}$, $0.33 \mathrm{mg} / \mathrm{ml}$ nitro blue tetrazolium, and $0.17 \mathrm{mg} / \mathrm{ml}$ 5-bromo-4-chloro-3-indolyl

Table 1. Number of fields surveyed and random samples collected from different provinces

\begin{tabular}{llcc}
\hline Province & Location & $\begin{array}{c}\text { Fields } \\
\text { surveyed (no.) }\end{array}$ & $\begin{array}{c}\text { Leaf samples } \\
\text { (no.) }^{\mathbf{a}}\end{array}$ \\
\hline Azarbayejan-e-gharbi & $\begin{array}{l}\text { Khoy, Miandoab, Qareh ziya'eddin, } \\
\text { Vishleq-e-olya }\end{array}$ & 6 & 276 \\
Esfahan & Borkhar, Esfahan & 14 & 630 \\
Fars & Eqlid (Asopas, Mandan) & 5 & 258 \\
Hamedan & Bahar & 3 & 184 \\
Kermanshah & Bisotun, Eslam abad-e-gharb, & 30 & 1,517 \\
Khorasan & $\quad$ Kangavar, Sahneh, Sonqor & 21 & 1,084 \\
Qazvin & Fariman, Jolgeh-rokh, Jovein, Neghab & 11 & 452 \\
Semnan & Ajorvand, Jannat-abad, Mehdi-abad, \\
Total & Lya, Yazbar & 16 & 891 \\
\hline
\end{tabular}

a All samples were tested by tissue-blot immunoassay using the available virus detection systems. before use. For AlMV, BWYV, CpCDV, and CMV, the same dilution of raw antisera in PBS was used. The membrane was washed and treated in 1:10,000 dilution of alkaline phosphatase-conjugated goat antirabbit IgG (Sigma Chemical Co., St. Louis, MO). All buffers used contained $0.02 \%$ sodium azide as a preservative. Development of blue-purple color in dotted areas was interpreted as infected samples. Positive and negative control samples for relevant viruses were used as controls in each virus assay.

Host range studies. Sugar beet leaf samples with positive reaction in TBIA (except for BCTV and CpCDV) were selected, and their reactions on eight plant species, Gomphrena globosa (Amarantha(Brassicaceae), B. vulgaris, Chenopodium amaranticolor, and $C$. quinoa (Chenopodiaceae), and Petunia hybrida and Nicotiana glutinosa (Solanaceae), were investigated. In mechanical transmission experiments, 0.1 M Na-phosphate buffer ( $\mathrm{pH} 7.0$ ) containing $0.2 \%$ sodium sulfite was used as a transmission assays, green peach aphids (Myzus persicae Sulzer) were allowed to feed on BWYV- or BYV-infected leaf samples for $24 \mathrm{~h}$ in sealed petri dishes. After the acquisition period, the aphids were placed on healthy indicator plants for an inoculation period of 48 to $72 \mathrm{~h}$ prior to killing with Primicarb (Bayer, Germany). At least three plants of each species were inoculated. In the host range assays, two or more replications were performed when results were negative or uncertain. The indicator plants were kept in an insect-free greenhouse with about $15 \mathrm{~h}$ light, at $25 \pm$ $5^{\circ} \mathrm{C}$ and 50 to $70 \%$ relative humidity, and were regularly observed during 1 to 4 weeks or longer after inoculation. The TBIA was used in addition to symptomology to detect and identify viruses in indicator host plants.

Electron microscopy. The procedure of Brlansky and Derrick (4) was used to trap virus particles. The precoated grids with Formvar and carbon were floated on the phosphate $p$-toluidine salt) prepared just ceae), Brassica rapa and Raphanus sativus general inoculation buffer. For aphid appropriate antiserum drops, diluted to

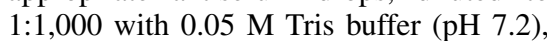
for 15 to $30 \mathrm{~min}$ at RT. Unabsorbed serum was removed by floating the grids for 5 min, or washing by 40 drops of Tris buffer. Experimental grids were immediately floated on crude sap extracts of selected field samples for 30 to $45 \mathrm{~min}$. Following the reaction, the grids were washed to remove plant debris by floating 3 to $5 \mathrm{~min}$ or washing by 40 drops of distilled water. Subsequently, the grids were stained using 4 to 5 drops of $1 \%$ uranyl acetate and examined for the presence of virus particles in a Phillips-TEM $301 \mathrm{G}$ transmission electron microscope.

\section{RESULTS}

Samplings. The typical virus disease symptoms observed in Iranian sugar beets included mosaic, chlorosis, yellowing, vein clearing, vein necrosis, stunting, and enation and curling of leaves. The most common symptoms observed in sugar beet fields of all surveyed provinces were chlorosis and yellowing (33.3\%) (Table 2). Based on leaf symptoms, about $39.1 \%$ of plants growing in these areas probably had a viral disease infection (Table 2).

Use of the TBIA technique greatly facilitated the detection of such a broad array of viruses tested in this study of Iranian sugar beet crops. However, the presence of viruses in the samples also was confirmed by electron microscopy and host range studies. The reactions of diseased and nondiseased plant samples in TBIA with the antisera used were clearly different (Fig. 1). Also, no serological crossreactivity was detected between Potyviridae viruses or between Geminiviridae viruses in our assays.

TBIA results with random sugar beet leaf samples indicated that viral disease incidence in decreasing order was BCTV (27.9\%), BWYV (17.4\%), CpCDV (12.5\%), BYV (10.6\%), BtMV (7.4\%), TuMV (2.9\%), AlMV (1.3\%), and CMV $(1.2 \%)$. BCTV was detected in 1,478 samples collected from 101 different fields. The incidence of this virus ranged from $8.6 \%$ in Qazvin to $53.9 \%$ in Fars. This virus was the most predominant problem in all provinces surveyed, except for Azarbayejan-e-gharbi (Table 3). Mild to severe symptoms were associated with BCTV infection in the fields. Plants severely infected with BCTV showed stunting, vein clearing and swelling, enations, thickening, upward and inward rolling of the leaves, and phloem exudates in some fields of Khorasan and Kermanshah.

Serological assays showed that CpCDV was more prevalent in Qazvin, Khorasan, and Kermanshah provinces, where this virus was detected in $87.1 \%$ of the fields surveyed. In other word, 555 out of 662 samples infected with CpCDV were found in the three aforementioned provinces (data not shown). Chlorosis and stunting 
symptoms were observed in association with plants affected with this virus.

Yellowing symptoms on young leaves were observed in samples with positive reaction in TBIA using BWYV polyclonal antibody. The results revealed viral incidence in Qazvin province $(58.2 \%)$ was mainly due to the occurrence of this virus where the highest incidence for BWYV was also recorded $(50.7 \%)$. Except for Hamedan, this virus was detected in the other provinces surveyed with considerable differences in incidence (Table 3). TBIA results also indicated that 18 symptomatic leaves collected from Ardabil had a positive reaction to BWYV polyclonal antibody.

The incidence of BYV recorded in Azarbayejan-e-gharbi (49.3\%) was considerably higher than that for other provinces (Table 3). Serological assays showed $100 \%$ of the samples randomly collected from two fields located in Miandoab area infected with BYV (data not shown). Chlorosis, yellowing, vein clearing, necrosis, and stunting were usually observed in BYV positively reacted sugar beet samples in TBIA tests collected from different provinces surveyed.

Field symptoms associated with virus infection of the samples by AlMV, BtMV, CMV, and TuMV were similar and included mosaic, mottling, and vein clearing. BtMV was the most prevalent virus in Khorasan (23.8\%), followed by Qazvin, Hamedan, Kermanshah, Semnan, and Esfahan. This virus was not detected in Azarbayejan-e-gharbi, where BYV-infection was recorded at the highest incidence. The results also revealed the highest incidence of TuMV in Esfahan, which differed markedly from those recorded in the other provinces (Table 3).

The incidence of virus infection ranged from $17.4 \%$ in Hamedan to $58.2 \%$ in Qazvin. Overall, incidence of viral infection was estimated to be $45.5 \%$ (2,406 samples) in the surveyed provinces. All of the 106 fields studied had viral infection with a range of 6.1 to $100 \%$ (Table 3). Moreover, except for Azarbayejan-e-gharbi and Qaz- vin, leafhopper-vectored viruses were more prevalent $(34.8 \%)$ than those transmitted by aphids $(27.8 \%$ ) (Table 3 ). In all provinces surveyed except for Hamedan, Khorasan, and Qazvin, viral disease incidence as single infections was higher than that of mixed infections between the leafhopper and aphid transmissible viruses. Totally, 25.7 and $19.7 \%$ of the randomly collected sugar beet samples had single and mixed infections, respectively (Table 4). High levels of mixed infections were found between BCTV and $\mathrm{CpCDV}$, and BtMV, BWYV, and BYV (Table 5). Among aphid-vectored virus/virus combinations, coinfection of samples with BtMV-BWYV, BtMV-BYV, or BWYVBYV occurred at the highest incidence in almost all provinces surveyed except for Esfahan, where mixed infection between BWYV and TuMV was higher (Table 6).

Both symptom incidence and serological assay results revealed a large variation in virus incidence among the different fields surveyed. However, virus incidence assessment based on visual symptoms either underestimated or overestimated virus incidence as determined by laboratory testing of randomly collected samples. While virus incidence assessed by serological tests and visually observed symptoms closely matched in some provinces, there was a very poor match in others (Tables 2 and 3 ).

Host range studies and electron microscopy. Our BtMV isolates systemically infected B. vulgaris and induced local lesions on C. quinoa and G. globosa. In contrast, TuMV isolated from sugar beet produced necrotic local lesions on $N$. glutinosa followed by systemic and top necrosis symptoms. TuMV also caused systemic infection of $P$. hybrida and B. rapa. These viruses had flexuous filamentous particles with about 720 to $730 \mathrm{~nm}$, characteristic of the Potyviridae family. BYV isolates had long flexuous filamentous particles, and caused yellowing on B. vulgaris. Systemic infection of the studied BWYV isolates resulted in yellowing on $B$. vulgaris and $R$. sativus. Electron microscopy of trapped particles from leaf extracts of the infected plants showed isometric particles with diameters of about 25 to $27 \mathrm{~nm}$. Inoculation of AlMV and CMV isolated from sugar beet plants caused chlorotic local lesions on $C$. amaranticolor and $C$. quinoa, and mosaic on $N$. glutinosa. Host ranges and symptoms of these two viruses were similar. However, they had bacilliform and isometric particles, respectively. Additionally, geminate particles were observed in leaf extracts of samples which had positive reactions in TBIA using BCTV- and CpCDV-specific antisera. This information was obtained as a secondary

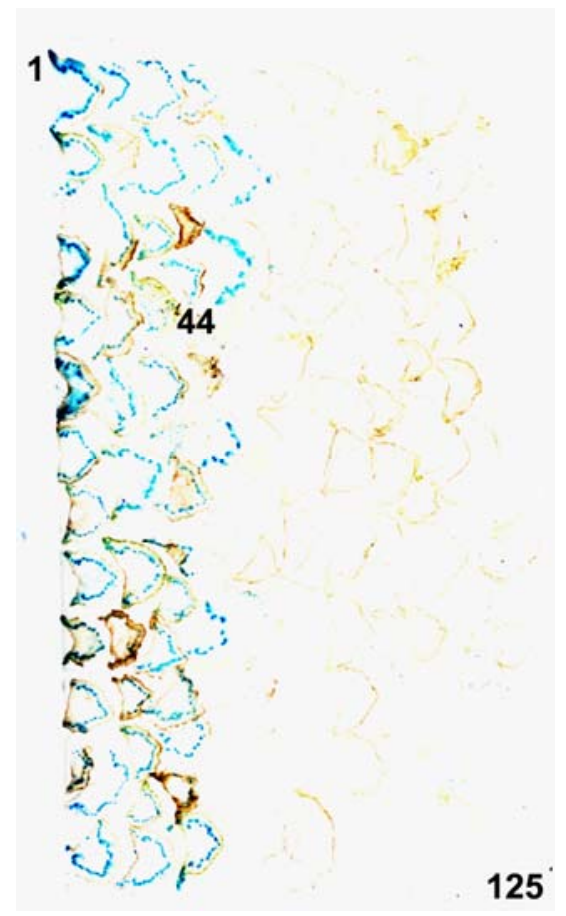

Fig. 1. Immunochemical detection of Beet yellows virus (BYV) in leaf samples using tissueblot immunoassay on nitrocellulose membrane. The incidence of BYV in a field of Azarbayejan-e-gharbi (Miandoab) with up to $100 \%$ infection (1 to 44) was compared with other fields with lower incidence of this virus (45 to 125). Reactions of darker, diseased plants are presented.

Table 2. Virus symptoms observed in the surveyed provinces $(\%)^{\mathrm{a}}$

\begin{tabular}{|c|c|c|c|c|c|c|c|}
\hline \multirow[b]{2}{*}{ Province } & \multicolumn{7}{|c|}{ Symptoms } \\
\hline & $\begin{array}{c}\text { Enation, } \\
\text { leaf curling }\end{array}$ & Mosaic & Necrosis & Stunting & Vein clearing & $\begin{array}{l}\text { Chlorosis, } \\
\text { yellowing }\end{array}$ & Cumulative $^{\mathrm{b}}$ \\
\hline Azarbayejan-e-gharbi & $3.2^{\mathrm{c}}$ & 17.0 & 0.5 & 0.5 & 19.0 & 47.8 & 56.8 \\
\hline Esfahan & 14.0 & 3.5 & 0.7 & 4.1 & 3.3 & 17.1 & 23.3 \\
\hline Fars & 57.2 & 6.0 & 1.0 & 29.4 & 24.6 & 61.4 & 74.2 \\
\hline Hamedan & 1.0 & 1.3 & 0.7 & 0.7 & 2.0 & 4.3 & 6.0 \\
\hline Kermanshah & 15.8 & 2.8 & 1.2 & 2.7 & 2.5 & 33.2 & 39.7 \\
\hline Khorasan & 38.0 & 3.1 & 1.3 & 3.1 & 17.7 & 43.5 & 48.7 \\
\hline Qazvin & 5.1 & 1.0 & 0.9 & 0.3 & 0.4 & 13.4 & 17.8 \\
\hline Semnan & 9.7 & 2.1 & 3.1 & 11.6 & 3.4 & 39.2 & 42.3 \\
\hline Average $^{\mathrm{d}}$ & 18.7 & 3.6 & 1.3 & 5.1 & 7.5 & 33.3 & 39.1 \\
\hline
\end{tabular}

a The highest percentage of symptoms observed in sugar beet fields in each province is shown in bold.

${ }^{\mathrm{b}}$ Estimated virus incidence in each province based on virus-like symptoms observed in the surveyed fields. Some plants had multiple virus-like symptoms.

${ }^{c}$ Virus disease symptoms incidence.

${ }^{\mathrm{d}}$ Incidence of each symptom in the surveyed provinces. 
confirmation of infection for these viruses. The results for viruses tested were generally in agreement with those reported by others $(1,5,6,17,23,31,33,37,38)$.

\section{DISCUSSION}

In this work, BCTV was detected in almost all surveyed fields (Tables 3, 5, and $6)$, suggesting its occurrence in Iran wherever sugar beets are grown. The virus caused persistent symptoms and was associated with very severe symptoms in some plants. These observations propose BCTV as the most important insect-borne virus that infects sugar beets in Iran. Recent works on the detection of an Iranian isolate of BCTV showed that it is similar to Beet severe curly top virus (3). In our study, different symptoms were observed in the sugar beet fields showing curly top disease (CTD), indicating different viruses are probably associated with CTD in Iran, which will need to be confirmed through molecular and biological evidence.

We found that some plants with positive reaction in serological assays with CpCDV antiserum did not show any observable symptoms, which confirms previous reports (17). This Mastrevirus (39) was detected less frequently than BCTV in the samples tested. The results indicate the infection of sugar beets in Iran with a gem- inivirus serologically related to $\mathrm{CpCDV}$. In addition, a DNA fragment of $301 \mathrm{bp}$ of this sugar beet infecting Mastrevirus from Khorasan (Kh8) was sequenced (GenBank accession no. DQ159207). Blast search results revealed the highest identity of this sequence to another dicot-infecting mastrevirus, Bean yellow dwarf virus $(91.0 \%)$ (data not shown). Recent works indicated that over $50 \%$ of the sugar beet leaf samples randomly collected from Kermanshah and Khorasan provinces, the two main areas for sugar beet cultivation in Iran, had positive reaction in TBIA using CpCDVspecific antibody (our unpublished data). It seems that the prevalence and importance of this Mastrevirus is increasing in Iran. However, more studies are necessary to determine characteristics of this sugar beet Mastrevirus. The preliminary results of this study was reported earlier (11).

Our results indicated that nearly $35 \%$ of sugar beets in Iran were infected by one or both of BCTV and CpCDV, which were detected in 104 out of 106 fields surveyed. These viruses are reported to be transmitted by leafhoppers $(17,37)$, which were more abundant in sugar beet fields of Iran than aphids (our personal observations). Also, among the leafhopper vectors of BCTV (37), Circulifer tenellus Baker and C. opacipennis Lethierry have been re- ported in the sugar beet fields (25). Orosius orientalis Matsumura, the vector for CpCDV (17), has not been identified in Iran. O. albicinctus Distant, another species in the genus Orosius, was observed in Iran (25), but its possible role in transmission of the sugar beet Mastrevirus remains to be confirmed.

The obtained data suggest that among insect-vectored viruses, BYV is the second most prevalent virus in Iran. Additionally, the results indicated a positive reaction for 919 (17.4\%) samples using BWYV polyclonal antibody. Serological relationships among luteoviruses (41) indicate the possible incidence of different viruses belonging to the genus Polerovirus in sugar beets of Iran. This study revealed the occurrence of TuMV in some provinces of Iran, especially in Esfahan, where ornamental and arable brassicas are grown in close proximity. This results in a reservoir of TuMVinfected plants and availability of a constant inoculum source for aphid vectors, as reported previously (40). Several aphid vectors of sugar beet viruses have been previously identified in Iran (32); however, Aphis fabae Scopuli was observed to be the most prevalent colonizing aphid in the surveyed sugar beet fields (our personal observations). The important role of noncolonizing winged aphids especially in

Table 3. Results of laboratory tests (\%) run on random leaf sugar beet samples taken from 106 fields in Iran during $2001^{\mathrm{a}, \mathrm{b}}$

\begin{tabular}{|c|c|c|c|c|c|c|c|c|c|c|c|}
\hline \multirow[b]{2}{*}{ Province } & \multicolumn{11}{|c|}{ Virus infection } \\
\hline & AlMV & BCTV & BtMV & BWYV & BYV & CpCDV & CMV & TuMV & Aph.c & Leaf. $^{d}$ & Overalle $^{\mathrm{e}}$ \\
\hline $\begin{array}{l}\text { Azarbayejan- } \\
\text { e-gharbi }\end{array}$ & 0.0 & $\begin{array}{c}10.9^{\mathrm{f}} \\
0.0-27.3^{\mathrm{g}} \\
(4)^{\mathrm{h}}\end{array}$ & 0.0 & $\begin{array}{c}2.2 \\
0.0-10.5 \\
(2)\end{array}$ & $\begin{array}{c}\mathbf{4 9 . 3} \\
4.8-100 \\
(6)\end{array}$ & 0.0 & 0.0 & 0.0 & $\begin{array}{c}50.0 \\
7.4-100 \\
(6)\end{array}$ & $\begin{array}{c}10.9 \\
0.0-27.3 \\
(4)\end{array}$ & $\begin{array}{c}51.4 \\
7.4-100 \\
(6)\end{array}$ \\
\hline Esfahan & 0.0 & $\begin{array}{c}\text { 36.7 } \\
15.4-50.9 \\
(14)\end{array}$ & $\begin{array}{c}0.6 \\
0.0-7.0 \\
(1)\end{array}$ & $\begin{array}{c}15.2 \\
0.0-37.5 \\
(10)\end{array}$ & $\begin{array}{c}2.5 \\
0.0-14.0 \\
(6)\end{array}$ & $\begin{array}{c}2.4 \\
0.0-21.1 \\
(4)\end{array}$ & $\begin{array}{c}4.0 \\
0.0-37.5 \\
(6)\end{array}$ & $\begin{array}{c}21.0 \\
0.0-100 \\
(6)\end{array}$ & $\begin{array}{c}34.6 \\
0.0-100 \\
(13)\end{array}$ & $\begin{array}{c}37.1 \\
15.4-54.4 \\
(14)\end{array}$ & $\begin{array}{c}53.3 \\
25.0-100 \\
(14)\end{array}$ \\
\hline Fars & 0.0 & $\begin{array}{c}\mathbf{5 3 . 9} \\
39.6-68.5 \\
(5)\end{array}$ & 0.0 & $\begin{array}{c}6.2 \\
0.0-9.3 \\
(4)\end{array}$ & 0.0 & $\begin{array}{c}3.1 \\
0.0-9.3 \\
(2)\end{array}$ & 0.0 & 0.0 & $\begin{array}{c}6.2 \\
0.0-9.3 \\
(4)\end{array}$ & $\begin{array}{c}55.0 \\
39.6-68.5 \\
(5)\end{array}$ & $\begin{array}{c}56.6 \\
43.8-72.2 \\
(5)\end{array}$ \\
\hline Hamedan & 0.0 & $\begin{array}{c}\text { 12.0 } \\
6.3-20.0 \\
(3)\end{array}$ & $\begin{array}{c}4.3 \\
0.0-10.0 \\
(2)\end{array}$ & 0.0 & $\begin{array}{c}8.7 \\
3.3-12.5 \\
(3)\end{array}$ & 0.0 & 0.0 & 0.0 & $\begin{array}{c}9.8 \\
6.7-12.5 \\
(3)\end{array}$ & $\begin{array}{c}12.0 \\
6.3-20.0 \\
\text { (3) }\end{array}$ & $\begin{array}{c}17.4 \\
10.0-26.7 \\
(3)\end{array}$ \\
\hline Kermanshah & $\begin{array}{c}0.9 \\
0.0-7.7 \\
(7)\end{array}$ & $\begin{array}{c}\mathbf{3 3 . 3} \\
5.8-61.5 \\
(30)\end{array}$ & $\begin{array}{c}4.0 \\
0.0-18.8 \\
(18)\end{array}$ & $\begin{array}{c}20.8 \\
3.8-47.5 \\
(30)\end{array}$ & $\begin{array}{c}11.4 \\
1.6-32.7 \\
(30)\end{array}$ & $\begin{array}{c}11.7 \\
0.0-50.0 \\
(23)\end{array}$ & $\begin{array}{c}0.1 \\
0.0-1.6 \\
(1)\end{array}$ & $\begin{array}{c}0.7 \\
0.0-6.8 \\
(5)\end{array}$ & $\begin{array}{c}24.1 \\
3.8-50.0 \\
(30)\end{array}$ & $\begin{array}{c}38.4 \\
9.4-61.5 \\
(30)\end{array}$ & $\begin{array}{c}43.8 \\
14.1-61.5 \\
(30)\end{array}$ \\
\hline Khorasan & $\begin{array}{c}4.3 \\
0.0-20.0 \\
(9)\end{array}$ & $\begin{array}{c}\mathbf{2 4 . 9} \\
0.0-59.4 \\
(20)\end{array}$ & $\begin{array}{c}23.8 \\
0.0-60.0 \\
(20)\end{array}$ & $\begin{array}{c}15.1 \\
0.0-75.0 \\
(20)\end{array}$ & $\begin{array}{c}13.3 \\
0.0-34.4 \\
(20)\end{array}$ & $\begin{array}{c}23.6 \\
5.8-40.6 \\
(21)\end{array}$ & 0.0 & $\begin{array}{c}0.6 \\
0.0-9.6 \\
(3)\end{array}$ & $\begin{array}{c}32.7 \\
5.4-75.0 \\
(21)\end{array}$ & $\begin{array}{c}37.0 \\
10.9-68.8 \\
(21)\end{array}$ & $\begin{array}{c}46.4 \\
15.6-87.5 \\
(21)\end{array}$ \\
\hline Qazvin & $\begin{array}{c}1.3 \\
0.0-11.1 \\
(1)\end{array}$ & $\begin{array}{c}8.6 \\
0.0-25.9 \\
(9)\end{array}$ & $\begin{array}{c}10.2 \\
0.0-42.6 \\
(8)\end{array}$ & $\begin{array}{c}\mathbf{5 0 . 7} \\
23.3-74.1 \\
(11)\end{array}$ & $\begin{array}{c}8.6 \\
0.0-20.4 \\
(10)\end{array}$ & $\begin{array}{c}26.8 \\
0.0-50.0 \\
(10)\end{array}$ & 0.0 & $\begin{array}{c}0.9 \\
0.0-5.6 \\
(2)\end{array}$ & $\begin{array}{c}51.3 \\
23.3-74.1 \\
(11)\end{array}$ & $\begin{array}{c}33.2 \\
3.3-59.3 \\
(11)\end{array}$ & $\begin{array}{c}58.2 \\
30.0-79.6 \\
(11)\end{array}$ \\
\hline Semnan & $\begin{array}{c}0.3 \\
0.0-4.2 \\
(2)\end{array}$ & $\begin{array}{c}27.2 \\
6.1-40.4 \\
(16)\end{array}$ & $\begin{array}{c}1.5 \\
0.0-10.4 \\
(5)\end{array}$ & $\begin{array}{c}10.4 \\
0.0-32.7 \\
(13)\end{array}$ & $\begin{array}{c}3.9 \\
0.0-23.1 \\
(8)\end{array}$ & $\begin{array}{c}9.4 \\
0.0-69.2 \\
(8)\end{array}$ & $\begin{array}{c}4.0 \\
0.0-38.5 \\
(4)\end{array}$ & 0.0 & $\begin{array}{c}14.6 \\
0.0-51.9 \\
(13)\end{array}$ & $\begin{array}{c}31.3 \\
6.1-69.2 \\
(16)\end{array}$ & $\begin{array}{c}35.9 \\
6.1-71.2 \\
(16)\end{array}$ \\
\hline Average ${ }^{\mathrm{i}}$ & $\begin{array}{c}1.3 \\
0.0-20.0 \\
(19)\end{array}$ & $\begin{array}{c}\mathbf{2 7 . 9} \\
0.0-68.5 \\
(101)\end{array}$ & $\begin{array}{c}7.4 \\
0.0-60.0 \\
(54)\end{array}$ & $\begin{array}{c}17.4 \\
0.0-75.0 \\
(90)\end{array}$ & $\begin{array}{c}10.6 \\
0.0-100 \\
(83)\end{array}$ & $\begin{array}{c}12.5 \\
0.0-69.2 \\
(68)\end{array}$ & $\begin{array}{c}1.2 \\
0.0-38.5 \\
(11)\end{array}$ & $\begin{array}{c}2.9 \\
0.0-100 \\
(16)\end{array}$ & $\begin{array}{c}27.8 \\
0.0-100 \\
(101)\end{array}$ & $\begin{array}{c}34.8 \\
0.0-69.2 \\
(104)\end{array}$ & $\begin{array}{c}45.5 \\
6.1-100 \\
(106)\end{array}$ \\
\hline
\end{tabular}

a The highest incidence of virus infections in each province is shown in bold.

${ }^{\mathrm{b}}$ Identification was based on serological reactions (tissue-blot immunoassay).

${ }^{\mathrm{c}}$ Incidence of viruses that can be transmitted by aphids.

${ }^{\mathrm{d}}$ Incidence of leafhopper-transmissible viruses.

e Total virus incidence in each province calculated on the basis of single or mixed virus infections found in randomly collected samples.

${ }^{\mathrm{f}}$ Average of percent virus incidence.

$\mathrm{g}$ Range of percent virus incidence.

${ }^{\mathrm{h}}$ Number of fields with virus infection.

${ }^{\mathrm{i}}$ Incidence of each virus in the surveyed provinces. 
spreading of stylet-borne viruses is well documented (18).

The eight viruses identified to infect sugar beet are vectored by insects (six by aphids and two by leafhoppers). Leafhopper-transmitted viruses were often more prevalent than those transmitted by aphids in the surveyed provinces (Table 3). We

Table 4. Percentage of single and mixed virus infections occurring in sugar beet fields in different provinces of $\operatorname{Iran}^{\mathrm{a}}$

\begin{tabular}{lccc}
\hline Province & Single & Mix & Overall \\
\hline Azarbayejan-e-gharbi & $\mathbf{4 2 . 0}^{\mathbf{b}}$ & 9.4 & 51.4 \\
& $7.4-95.5^{\mathbf{c}}$ & $0.0-27.3$ & $7.4-100$ \\
Esfahan & $(6)^{\mathrm{d}}$ & $(5)$ & $(6)$ \\
& $\mathbf{3 1 . 3}$ & 22.1 & 53.3 \\
Fars & $17.5-46.3$ & $0.0-54.8$ & $25.0-100$ \\
& $(14)$ & $(13)$ & $(14)$ \\
& $\mathbf{5 0 . 4}$ & 6.2 & 56.6 \\
Hamedan & $41.4-63.0$ & $0.0-11.1$ & $43.8-72.2$ \\
& $(5)$ & $(4)$ & $(5)$ \\
Kermanshah & $\mathbf{8 . 7}$ & $\mathbf{8 . 7}$ & 17.4 \\
& $6.3-13.3$ & $3.3-13.3$ & $10.0-26.7$ \\
Khorasan & $(3)$ & $(3)$ & $(3)$ \\
& $\mathbf{2 2 . 9}$ & 20.8 & 43.8 \\
& $7.8-51.9$ & $2.1-45.0$ & $14.1-61.5$ \\
Qazvin & $(30)$ & $(30)$ & $(30)$ \\
& 19.8 & $\mathbf{2 6 . 6}$ & 46.4 \\
& $7.8-30.8$ & $7.1-62.5$ & $15.6-87.5$ \\
Semnan & $(21)$ & $(21)$ & $(21)$ \\
& 28.8 & $\mathbf{2 9 . 4}$ & 58.2 \\
& $13.3-50.0$ & $0.0-64.8$ & $30.0-79.6$ \\
Average & $(11)$ & $(10)$ & $(11)$ \\
& $\mathbf{2 3 . 6}$ & 12.3 & 35.9 \\
& $6.1-35.0$ & $0.0-51.9$ & $6.1-71.2$ \\
& $(16)$ & $(14)$ & $(16)$ \\
& $\mathbf{2 5 . 7}$ & 19.7 & 45.5 \\
& $6.1-95.5$ & $0.0-64.8$ & $6.1-100$ \\
& $(106)$ & $(100)$ & $(106)$ \\
\hline
\end{tabular}

a The highest incidence of virus infections in each province is shown in bold.

${ }^{\mathrm{b}}$ Average of percent virus incidence.

${ }^{\mathrm{c}}$ Range of percent virus incidence.

$\mathrm{d}$ Number of fields with virus infection.

showed that in the areas surveyed, mixed infections occurred at high frequencies between viruses that can induce chlorosis to yellowing symptoms on sugar beet plants, including BCTV, BtMV, BWYV, BYV, and CpCDV (Tables 5 and 6). This indicates that the vectors might be attracted by the yellow color of virusinfected plants $(7,19,43)$. Alternatively, such affected plants may release specific volatiles that attract the vectors, as reported previously for Potato leaf roll virus-infected potato plants attracting the aphid vector Myzus persicae (8). The results indicated considerable differences of incidence for each of the viruses tested in the same province (Table 3), in contrast to some of the studied viruses that have common vectors. For example, while the most prevalent virus in Azarbayejan-egharbi was BYV, it is very surprising that no BtMV was observed, and so little BWYV was detected. Also, the three viruses were detected in Qazvin with the highest incidence of BWYV (Table 3). Among viruses transmitted by aphids, the most prevalent coinfection occurring in almost all provinces was recorded between BtMV, BWYV, or BYV, except for Esfahan, where high incidence of mixed infections was recorded for BWYV and TuMV. In addition, comparison of Tables 3 and 6 revealed that the incidences of mixed infections, e.g., BtMV-BWYV (Kermanshah, Qazvin, Semnan), BWYV-BYV (Qazvin), and BWYV-TuMV (Qazvin), are close to the overall incidences of BtMV, BYV, and

Table 5. Percentage of mixed infections occurring between leafhopper- and aphid-transmitted viruses in sugar beet fields in Iran ${ }^{a}$

\begin{tabular}{|c|c|c|c|c|c|c|c|c|c|c|c|c|c|}
\hline \multirow[b]{3}{*}{ Province } & \multicolumn{13}{|c|}{ Percent random sugar beet samples infected with combinations of two viruses } \\
\hline & \multicolumn{7}{|c|}{ BCTV } & \multicolumn{6}{|c|}{ CpCDV } \\
\hline & AIMV & BtMV & BWYV & BYV & CpCDV & CMV & TuMV & AIMV & BtMV & BWYV & BYV & CMV & TuMV \\
\hline $\begin{array}{l}\text { Azarbayejan- } \\
\text { e-gharbi }\end{array}$ & 0.0 & 0.0 & $\begin{array}{c}1.4^{\mathrm{b}} \\
0.0-10.5^{\mathrm{c}} \\
(1)^{\mathrm{d}}\end{array}$ & $\begin{array}{c}\mathbf{9 . 4} \\
0.0-27.3 \\
(4)\end{array}$ & 0.0 & 0.0 & 0.0 & 0.0 & 0.0 & 0.0 & 0.0 & 0.0 & 0.0 \\
\hline Esfahan & 0.0 & $\begin{array}{c}0.6 \\
0.0-7.0 \\
(1)\end{array}$ & $\begin{array}{c}\mathbf{9 . 4} \\
0.0-27.5 \\
(9)\end{array}$ & $\begin{array}{c}1.9 \\
0.0-12.3 \\
(4)\end{array}$ & $\begin{array}{c}1.9 \\
0.0-17.5 \\
(3)\end{array}$ & $\begin{array}{c}2.1 \\
0.0-20.0 \\
(5)\end{array}$ & $\begin{array}{c}8.6 \\
0.0-40.5 \\
(6)\end{array}$ & 0.0 & $\begin{array}{c}0.5 \\
0.0-5.3 \\
(1)\end{array}$ & $\begin{array}{c}1.6 \\
0.0-14.0 \\
(3)\end{array}$ & $\begin{array}{c}1.4 \\
0.0-14.0 \\
(2)\end{array}$ & 0.0 & $\begin{array}{c}0.3 \\
0.0-3.5 \\
(1)\end{array}$ \\
\hline Fars & 0.0 & 0.0 & $\begin{array}{c}\mathbf{4 . 7} \\
0.0-8.9 \\
(4)\end{array}$ & 0.0 & $\begin{array}{c}1.9 \\
0.0-5.6 \\
(2)\end{array}$ & 0.0 & 0.0 & 0.0 & 0.0 & $\begin{array}{c}0.4 \\
0.0-1.9 \\
(1)\end{array}$ & 0.0 & 0.0 & 0.0 \\
\hline Hamedan & 0.0 & 0.0 & 0.0 & 0.0 & 0.0 & 0.0 & 0.0 & 0.0 & 0.0 & 0.0 & 0.0 & 0.0 & 0.0 \\
\hline Kermanshah & $\begin{array}{c}0.6 \\
0.0-7.7 \\
(6)\end{array}$ & $\begin{array}{c}2.8 \\
0.0-14.6 \\
(17)\end{array}$ & $\begin{array}{c}\mathbf{1 3 . 3} \\
0.0-40.4 \\
(29)\end{array}$ & $\begin{array}{c}8.2 \\
0.0-30.8 \\
(26)\end{array}$ & $\begin{array}{c}6.5 \\
0.0-25.0 \\
(23)\end{array}$ & 0.0 & $\begin{array}{c}0.3 \\
0.0-4.5 \\
(3)\end{array}$ & $\begin{array}{c}0.8 \\
0.0-7.7 \\
(5)\end{array}$ & $\begin{array}{c}2.5 \\
0.0-10.7 \\
(14)\end{array}$ & $\begin{array}{c}7.8 \\
0.0-42.5 \\
(22)\end{array}$ & $\begin{array}{c}5.3 \\
0.0-23.1 \\
(20)\end{array}$ & 0.0 & $\begin{array}{c}0.4 \\
0.0-6.3 \\
(3)\end{array}$ \\
\hline Khorasan & $\begin{array}{c}3.1 \\
0.0-16.7 \\
(8)\end{array}$ & $\begin{array}{c}\mathbf{1 3 . 7} \\
0.0-41.7 \\
(18)\end{array}$ & $\begin{array}{c}10.4 \\
0.0-43.8 \\
(19)\end{array}$ & $\begin{array}{c}8.6 \\
0.0-25.0 \\
(19)\end{array}$ & $\begin{array}{c}12.3 \\
0.0-30.0 \\
(19)\end{array}$ & 0.0 & $\begin{array}{c}0.2 \\
0.0-3.1 \\
(2)\end{array}$ & $\begin{array}{c}3.1 \\
0.0-15.0 \\
(8)\end{array}$ & $\begin{array}{c}13.5 \\
0.0-36.7 \\
(20)\end{array}$ & $\begin{array}{c}10.1 \\
0.0-37.5 \\
(19)\end{array}$ & $\begin{array}{c}8.6 \\
0.0-23.1 \\
(20)\end{array}$ & 0.0 & $\begin{array}{c}0.4 \\
0.0-7.7 \\
(1)\end{array}$ \\
\hline Qazvin & $\begin{array}{c}0.2 \\
0.0-1.9 \\
(1)\end{array}$ & $\begin{array}{c}1.5 \\
0.0-11.1 \\
(2)\end{array}$ & $\begin{array}{c}5.5 \\
0.0-20.4 \\
(5)\end{array}$ & $\begin{array}{c}1.1 \\
0.0-7.7 \\
(3)\end{array}$ & $\begin{array}{c}2.2 \\
0.0-9.3 \\
(4)\end{array}$ & 0.0 & $\begin{array}{c}0.4 \\
0.0-1.9 \\
(2)\end{array}$ & $\begin{array}{c}0.9 \\
0.0-7.4 \\
(1)\end{array}$ & $\begin{array}{c}7.5 \\
0.0-35.2 \\
(6)\end{array}$ & $\begin{array}{c}\text { 23.0 } \\
0.0-42.6 \\
(10)\end{array}$ & $\begin{array}{c}6.9 \\
0.0-16.7 \\
(9)\end{array}$ & 0.0 & $\begin{array}{c}0.7 \\
0.0-5.6 \\
(1)\end{array}$ \\
\hline Semnan & $\begin{array}{c}0.2 \\
0.0-2.1 \\
(2)\end{array}$ & $\begin{array}{c}0.8 \\
0.0-6.3 \\
(5)\end{array}$ & $\begin{array}{c}\mathbf{7 . 1} \\
0.0-26.9 \\
(13)\end{array}$ & $\begin{array}{c}2.5 \\
0.0-15.4 \\
(7)\end{array}$ & $\begin{array}{c}5.3 \\
0.0-40.4 \\
(8)\end{array}$ & $\begin{array}{c}1.0 \\
0.0-10.4 \\
(3)\end{array}$ & 0.0 & 0.0 & $\begin{array}{c}0.9 \\
0.0-10.4 \\
(4)\end{array}$ & $\begin{array}{c}5.1 \\
0.0-30.8 \\
(7)\end{array}$ & $\begin{array}{c}2.9 \\
0.0-21.2 \\
(6)\end{array}$ & $\begin{array}{c}0.2 \\
0.0-4.2 \\
(1)\end{array}$ & 0.0 \\
\hline Average & $\begin{array}{c}0.9 \\
0.0-16.7 \\
(17)\end{array}$ & $\begin{array}{c}3.9 \\
0.0-41.7 \\
(43)\end{array}$ & $\begin{array}{c}\text { 9.0 } \\
0.0-43.8 \\
(80)\end{array}$ & $\begin{array}{c}5.3 \\
0.0-30.8 \\
(63)\end{array}$ & $\begin{array}{c}5.8 \\
0.0-40.4 \\
(59)\end{array}$ & $\begin{array}{c}0.4 \\
0.0-20.0 \\
(8)\end{array}$ & $\begin{array}{c}1.2 \\
0.0-40.5 \\
(13)\end{array}$ & $\begin{array}{c}0.9 \\
0.0-15.0 \\
(14)\end{array}$ & $\begin{array}{c}4.3 \\
0.0-36.7 \\
(45)\end{array}$ & $\begin{array}{c}7.3 \\
0.0-42.6 \\
(62)\end{array}$ & $\begin{array}{c}4.5 \\
0.0-23.1 \\
(57)\end{array}$ & $\begin{array}{c}0.04 \\
0.0-4.2 \\
(1)\end{array}$ & $\begin{array}{c}0.3 \\
0.0-7.7 \\
(6)\end{array}$ \\
\hline
\end{tabular}

\footnotetext{
a The highest incidence of virus/virus combinations in each province is shown in bold.

${ }^{b}$ Average of percent virus incidence.

c Range of percent virus incidence.

${ }^{d}$ Number of fields with virus infection.
} 
TuMV, respectively. In contrast, in other cases, such as coinfection between BWYV and TuMV in Esfahan, the incidence of this mixed infection differed considerably from the incidence of BWYV. Moreover, we observed large differences in virus incidence among fields in the same province or between different provinces (Table 3 ). It seems that differences between the vector populations in these areas and the presence of reservoir hosts for the viruses or vectors have an important role in viral disease incidence in different locations surveyed. For example, the aphidtransmitted viruses reported in this study, except for BtMV and BYV, have been previously reported from other hosts in Iran $(2,11,13,20,21,24,30,34)$ that may play a role as alternative hosts for sugar beet crops, as aforementioned for TuMV in Esfahan. In addition, the only provinces where the incidence of aphid-transmissible viruses was more than that of leafhoppertransmissible viruses were Azarbayejan-egharbi and Qazvin, which may be related to the greater abundance of gardens in these provinces. However, very little is available on sugar beet virus epidemiology and their vector activities in Iran. It should be said that time of sampling may also affect viral disease incidence recorded for each province or location.

Almost $65 \%$ of the 1,294 symptomatic plants tested positive with at least one of the eight virus-specific antibodies used. Although the symptoms may be induced by nonviral agents, these findings suggest that the eight viruses studied are largely responsible for the virus diseases of sugar beet in Iran. In addition, the high incidence of yellowing and curly top diseases causes some problems in observing new types of symptoms and detecting putative novel viruses. Some plants did not react with any available virus detection systems; however, they showed virus-like symptoms. Moreover, other symptoms of petiole elongation, root madness, and xylem necrosis were also observed in the studied fields. Therefore, more viruses than the eight tested in this study probably infect sugar beets in Iran, the rhizomania being the most significant disease (manuscript in preparation).

This survey was restricted to nine main sugar beet-growing areas and to one growing season. An extension of this survey to other areas of Iran may reveal the presence of more viruses and viral strains in the crop. It seems that sugar beet in Iran is probably damaged naturally by many virus infections with different modes of transmission, including those vectored by insects or fungus-like organisms. Therefore, several protective measures, such as the use of resistant or tolerant varieties, removal of sources of infection in or around fields, use of a fallow period or rotation for host crops to break the infection cycle, and spraying crops with insecticide to control the insect vectors, should be employed to reduce the level of virus infection in sugar beet crops. In addition, the availability of effective serological and/or molecular tools for virus confirmation and differentiation will be an important step in improving disease monitoring and ultimately disease management in Iran.

\section{ACKNOWLEDGMENTS}

This work was supported by the Plant Virology Department of PPDRI (Tehran). We are grateful to S. Winter, K. M. Makkouk, our colleagues N. Shahraeen, M. Bahar, V. Alavi, and S. Jalali who kindly provided us with the antisera and positive samples that were used in this study. We thank $\mathrm{H}$ R. Mojdehi and S. A. Alavi for their kindly advice. This research was carried out under projects no. 2 009-100000-11-0000-83048 to 83050 of PPDRI.

\section{LITERATURE CITED}

1. Agranovsky, A. A. 2000. Beet yellows virus. AAB Descriptions of Plant Viruses, No. 377.

2. Bahar, M., Danesh, D., and Dehghan, M. 1985. Turnip mosaic virus in stock plant. Iran. J. Plant Pathol. 21:11.

3. Briddon, R. W., Stenger, D. C., Bedford, I. D. Stanley, J., Izadpanah, K., and Markham, P. G. 1998. Comparison of a beet curly top virus isolate originating from the old world with those from the new world. Eur. J. Plant Pathol. 104:77-84.

4. Brlansky, R. H., and Derrik, K. S. 1979. Detection of seedborne plant viruses using serologically specific electron microscopy. Phytopathology 69:96-100.

5. Brunt, A. A., Crabtree, K., Dallwitz, M. J., Gibbs, A. J., and Watson, L. 1995. Viruses of plants: Description and lists from the VIDE database. CAB International, Wallingford, UK

6. Duffus, J. E. 1972. Beet western yellows virus AAB Descriptions of Plant Viruses, No. 89.

7. Eastop, V. F., and Raccah, B. 1988. Aphid and host plant species in the Arava Valley of Israel:

Table 6. Percentage of mixed infections occurring between aphid-transmissible viruses in different provinces of Iran ${ }^{\mathrm{a}}$

\begin{tabular}{|c|c|c|c|c|c|c|c|c|c|c|c|c|c|c|}
\hline \multirow[b]{3}{*}{ Province } & \multicolumn{14}{|c|}{ Percent random sugar beet samples infected with combinations of two viruses } \\
\hline & \multicolumn{4}{|c|}{ AlMV } & \multicolumn{4}{|c|}{ BtMV } & \multicolumn{3}{|c|}{ BWYV } & \multicolumn{2}{|c|}{ BYV } & \multirow{2}{*}{$\frac{\text { CMV }}{\text { TuMV }}$} \\
\hline & BtMV & BWYV & BYV & TuMV & BWYV & BYV & CMV & TuMV & BYV & CMV & TuMV & CMV & TuMV & \\
\hline $\begin{array}{l}\text { Azarbayejan- } \\
\text { e-gharbi }\end{array}$ & 0.0 & 0.0 & 0.0 & 0.0 & 0.0 & 0.0 & 0.0 & 0.0 & $\begin{array}{c}\mathbf{1 . 4}^{\mathbf{c}} \\
0.0-10.5^{\mathrm{d}} \\
(1)^{\mathrm{e}}\end{array}$ & 0.0 & 0.0 & 0.0 & 0.0 & 0.0 \\
\hline Esfahan & 0.0 & 0.0 & 0.0 & 0.0 & $\begin{array}{c}0.5 \\
0.0-5.3 \\
(1)\end{array}$ & $\begin{array}{c}0.5 \\
0.0-5.3 \\
(1)\end{array}$ & 0.0 & $\begin{array}{c}0.3 \\
0.0-3.5 \\
(1)\end{array}$ & $\begin{array}{c}2.1 \\
0.0-14.0 \\
(4)\end{array}$ & $\begin{array}{c}0.6 \\
0.0-7.5 \\
(2)\end{array}$ & $\begin{array}{c}\mathbf{4 . 6} \\
0.0-23.8 \\
(5)\end{array}$ & 0.0 & $\begin{array}{c}0.6 \\
0.0-4.8 \\
(2)\end{array}$ & $\begin{array}{c}1.7 \\
0.0-20.0 \\
(4)\end{array}$ \\
\hline Fars & 0.0 & 0.0 & 0.0 & 0.0 & 0.0 & 0.0 & 0.0 & 0.0 & 0.0 & 0.0 & 0.0 & 0.0 & 0.0 & 0.0 \\
\hline Hamedan & 0.0 & 0.0 & 0.0 & 0.0 & 0.0 & $\begin{array}{c}\mathbf{3 . 3} \\
0.0-10.0 \\
(1)\end{array}$ & 0.0 & 0.0 & 0.0 & 0.0 & 0.0 & 0.0 & 0.0 & 0.0 \\
\hline Kermanshah & $\begin{array}{c}0.3 \\
0.0-6.3 \\
(2)\end{array}$ & $\begin{array}{c}0.8 \\
0.0-7.5 \\
(7)\end{array}$ & $\begin{array}{c}0.5 \\
0.0-6.3 \\
(4)\end{array}$ & $\begin{array}{c}0.2 \\
0.0-6.3 \\
(1)\end{array}$ & $\begin{array}{c}3.1 \\
0.0-10.7 \\
(17)\end{array}$ & $\begin{array}{c}3.2 \\
0.0-12.5 \\
(16)\end{array}$ & 0.0 & $\begin{array}{c}0.3 \\
0.0-6.3 \\
(2)\end{array}$ & $\begin{array}{c}\mathbf{8 . 7} \\
0.0-28.8 \\
(28)\end{array}$ & 0.0 & $\begin{array}{c}0.5 \\
0.0-6.8 \\
(3)\end{array}$ & 0.0 & $\begin{array}{c}0.3 \\
0.0-6.3 \\
(2)\end{array}$ & 0.0 \\
\hline Khorasan & $\begin{array}{c}3.6 \\
0.0-18.3 \\
(8)\end{array}$ & $\begin{array}{c}3.5 \\
0.0-15.4 \\
(8)\end{array}$ & $\begin{array}{c}2.7 \\
0.0-11.5 \\
(8)\end{array}$ & $\begin{array}{c}0.3 \\
0.0-5.8 \\
(1)\end{array}$ & $\begin{array}{c}\mathbf{9 . 6} \\
0.0-26.7 \\
(19)\end{array}$ & $\begin{array}{c}8.4 \\
0.0-25.0 \\
(18)\end{array}$ & 0.0 & $\begin{array}{c}0.4 \\
0.0-7.7 \\
\text { (1) }\end{array}$ & $\begin{array}{c}7.4 \\
0.0-34.4 \\
(19)\end{array}$ & 0.0 & $\begin{array}{c}0.4 \\
0.0-5.8 \\
(2)\end{array}$ & 0.0 & $\begin{array}{c}0.4 \\
0.0-7.7 \\
(1)\end{array}$ & 0.0 \\
\hline Qazvin & $\begin{array}{c}0.7 \\
0.0-5.6 \\
(1)\end{array}$ & $\begin{array}{c}1.3 \\
0.0-11.1 \\
(1)\end{array}$ & $\begin{array}{c}0.7 \\
0.0-5.6 \\
(1)\end{array}$ & $\begin{array}{c}0.2 \\
0.0-1.9 \\
\text { (1) }\end{array}$ & $\begin{array}{c}\mathbf{1 0 . 0} \\
0.0-42.6 \\
(8)\end{array}$ & $\begin{array}{c}4.2 \\
0.0-11.1 \\
(7)\end{array}$ & 0.0 & $\begin{array}{c}0.7 \\
0.0-5.6 \\
(1)\end{array}$ & $\begin{array}{c}8.2 \\
0.0-20.4 \\
(10)\end{array}$ & 0.0 & $\begin{array}{c}0.9 \\
0.0-5.6 \\
(2)\end{array}$ & 0.0 & $\begin{array}{c}0.2 \\
0.0-1.9 \\
(1)\end{array}$ & 0.0 \\
\hline Semnan & $\begin{array}{c}0.1 \\
0.0-2.1 \\
(1)\end{array}$ & $\begin{array}{c}0.3 \\
0.0-4.2 \\
(2)\end{array}$ & $\begin{array}{c}0.2 \\
0.0-4.2 \\
(1)\end{array}$ & 0.0 & $\begin{array}{c}1.2 \\
0.0-10.4 \\
(5)\end{array}$ & $\begin{array}{c}1.2 \\
0.0-10.4 \\
(5)\end{array}$ & $\begin{array}{c}0.2 \\
0.0-2.1 \\
(2)\end{array}$ & 0.0 & $\begin{array}{c}\mathbf{3 . 1} \\
0.0-17.3 \\
(7)\end{array}$ & $\begin{array}{c}0.7 \\
0.0-7.7 \\
(2)\end{array}$ & 0.0 & $\begin{array}{c}0.4 \\
0.0-5.8 \\
(2)\end{array}$ & 0.0 & 0.0 \\
\hline Average & $\begin{array}{c}0.9 \\
0.0-18.3 \\
(12)\end{array}$ & $\begin{array}{c}1.1 \\
0.0-15.4 \\
(18)\end{array}$ & $\begin{array}{c}0.8 \\
0.0-11.5 \\
(14)\end{array}$ & $\begin{array}{c}0.1 \\
0.0-6.3 \\
(3)\end{array}$ & $\begin{array}{c}4.0 \\
0.0-42.6 \\
(50)\end{array}$ & $\begin{array}{c}3.4 \\
0.0-25.0 \\
(48)\end{array}$ & $\begin{array}{c}0.04 \\
0.0-2.1 \\
(2)\end{array}$ & $\begin{array}{c}0.3 \\
0.0-7.7 \\
(5)\end{array}$ & $\begin{array}{c}\mathbf{5 . 6} \\
0.0-34.4 \\
(69)\end{array}$ & $\begin{array}{c}0.2 \\
0.0-7.7 \\
(4)\end{array}$ & $\begin{array}{c}0.8 \\
0.0-23.8 \\
(12)\end{array}$ & $\begin{array}{c}0.1 \\
0.0-5.8 \\
(2)\end{array}$ & $\begin{array}{c}0.3 \\
0.0-7.7 \\
(6)\end{array}$ & $\begin{array}{c}0.2 \\
0.0-20.0 \\
(4)\end{array}$ \\
\hline
\end{tabular}

a The highest incidence of virus/virus combinations in each province is shown in bold.

b Mixed infections between AlMV and CMV were not detected in randomly collected sugar beet leaf samples.

c Average of percent virus incidence.

${ }^{\mathrm{d}}$ Range of percent virus incidence.

e Number of fields with virus infection. 
Epidemiological aspect. Phytoparasitica 16:2332.

8. Eigenbrode, S. D., Ding, H., Shiel, P., and Berger, P. H. 2002. Volatiles from potato plants infected with potato leafroll virus attract and arrest the virus vector, Myzus persicae (Homoptera: Aphididae). Proc. R. Soc. London 269:455-460

9. FAO. 1999. FAOSTAT Database results from FAO website. Food and Agriculture Organization of the United Nations.

10. FAO. 2000. FAOSTAT Database results from FAO website. Food and Agriculture Organization of the United Nations.

11. Farzadfar, Sh., Pourrahim, R., Golnaraghi, A. R., Shahraeen, N., and Makkouk, K. M. 2002. First report of sugar beet and bean as natural hosts of chickpea chlorotic dwarf virus. Plant Pathol. 51:795.

12. Gibson, K. E. 1967. Possible incidence of curly top in Iran-A new record. Plant Dis. Rep. 51:976-977.

13. Golnaraghi, A. R., Shahraeen, N., Pourrahim, R., Farzadfar, Sh., and Ghasemi, A. 2004. Occurrence and relative incidence of viruses infecting soybeans in Iran. Plant Dis. 88:10691074.

14. Hajimorad, M. R., Kheyri, M., Bananej, K., and Herrbach, E. 1993. First report of occurrence and identification of beet mild yellowing luteovirus in Karaj, Iran. Page 131 in: Proc. Plant Prot. Congr. Iran, 11th. Rasht, Iran.

15. Hemmati, K., 1970. Role of Myzus persica Sulz. and Aphis fabae Scop. in transmiting of beet yellows virus and beet mosaic virus. Iran. J. Plant Pathol. 5:44.

16. Hemmati, K., and Alizadeh, J. 1971. New host of Cucumber mosaic virus in Iran. Iran. J. Plant Pathol. 6:43.

17. Horn, N. M., Reddy, S. V., Roberts, I. M., and Reddy, D. V. R. 1993. Chickpea chlorotic dwarf virus, a new leafhopper-transmitted geminivirus of chickpea in India. Ann. Appl. Biol. 122:467-479.

18. Hull, R. 2002. Matthews' plant virology. Academic Press, New York.

19. Irwin, M. E. 1980. Sampling aphids in soybean fields. Pages 239-259 in: Sampling Methods in Soybean Entomology. M. Kogan and D. C.
Hezog, eds. Springer-Verlag, New York.

20. Izadpanah, K. 1983. An annotated list of virus and virus-like diseases of plants in Fars. Department of Plant Protection, College of Agriculture, Shiraz University, Shiraz, Iran.

21. Jalali, S. 2001. Investigation on dissemination of beet curly top virus and identification of other cultivated hosts in Esfahan province. J. Sugar Beet 17:13.

22. Jalali, S., Okhovat, M., Mossahebi, G. H., and Arjmand, M. N. 2001. Isolation and identification viruses caused mosaic symptoms in sugar beet in Karaj. J. Sugar Beet 17:4.

23. Jaspars, E. M. J., and Bos, L. 1980. Alfalfa mosaic virus. AAB Descriptions of Plant Viruses, No. 229.

24. Kaiser, W. J., Mossahebi, G. H., and Okhovat, M. 1971. Alternate hosts of viruses affecting food legumes in Iran. Iran. J. Plant Pathol. 7:85.

25. Karimzadeh-esfahani, J. 1997. Fauna of Homoptera: Auchenorrhyncha in sugar beet fields of Esfahan province. M.Sc. thesis. Plant Protection Department, College of Agriculture, Tehran University, Iran.

26. Khakvar, R., Pourrahim, R., and Shamsbakhsh, M. 2000. Study on six potato viruses in Khuzestan provience. Page 312 in: Proc. Iranian Plant Prot. Congr., 14th. Isfahan University of Technology, Iran.

27. Kheyri, M., Alimoradi, I., and Davatchi, A. 1969. The leafhoppers of sugar beet in Iran and their role in curly-top virus disease. Sugar Beet Seed Institute, Karaj, Iran.

28. Lewellen, R. T., Wisler, G. C., Liu, H. Y., Kaffka, S. R., Sears, J. L., and Duffus, J. E. 1999. Reaction of sugar beet breeding lines and hybrids to beet chlorosis luteovirus. J. Sugar Beet Res. 36:76.

29. Lin, N. S., Hsu, Y. H., and Hsu, H. T. 1990. Immunological detection of plant viruses and a mycoplasmalike organism by direct tissue blotting on nitrocellulose membranes. Phytopathology 80: 824-828.

30. Makkouk, K. M., Kumari, S. G., Shahraeen, N., Fazlali, Y., Farzadfar, S., Ghotbi, T., and Mansouri, A. R. 2002. Identification and seasonal variation of viral diseases of chickpea and lentil in Iran. Z. Pflanzenkrankh. Pflanzen- schutz 110:157-169.

31. Palukaitis, P., and Garcia-Arenal, F. 2003. Cucumber mosaic virus. AAB Descriptions of Plant Viruses, No. 400.

32. Rezwani, A. 2001. Key to the aphids (Homoptera: Aphidinea) in Iran. Agricultural Research Education and Extension Organization, Ministry of Jihad-e-Agriculture, Tehran, Iran.

33. Russell, G. E. 1971. Beet mosaic virus. AAB Descriptions of Plant Viruses, No. 53.

34. Shahraeen, N., Farzadfar, Sh., and Lesemann, D. E. 2003. Incidence of viruses infecting winter oilseed rape (Brassica napus ssp. oleifera) in Iran. J. Phytopathol. 151:614-616.

35. Smith, H. G., and Hallsworth, P. B. 1990. The effects of yellowing viruses on yield of sugar beet in field trials, 1985 and 1987. Ann. Appl. Biol. 116:503-511.

36. Sutic, D. D., Ford, R. E., and Tosic, M. T. 1998. Handbook of Plant Virus Diseases. CRC Press, Boca Raton, FL.

37. Thomas, P. E. 1979. Beet curly top virus. AAB Descriptions of Plant Viruses, No. 210.

38. Tomlinson, J. A. 1970. Turnip mosaic virus AAB Descriptions of Plant Viruses, No. 8.

39. van Regenmortel, M. H. V., Fauquet, C. M. Bishop, D. H. L., Carstens, E. B., Estes, M. K., Lemon, S. M., Maniloff, J., Mayo, M. A., McGeoch, D. J., Pringle, C. R., and Wickner, R. B., eds. 2000. Virus Taxonomy: Classification and Nomenclature of Viruses, 7th Report of the International Committee on Taxonomy of Viruses. Academic Press, New York.

40. Walsh, J. A. 1986. Viruses in oilseed rape, a potential threat to vegetable crops. Asp. Appl. Biol. 12:59-68.

41. Waterhouse, P. M., Gildow, F. E., and Johnstone, G. R. 1988. Luteovirus group. AAB Descriptions of Plant Viruses, No. 339.

42. Whitney, E. D., and Duffus, E., eds. 1998 Compendium of Beet Diseases and Insects. 3rd ed. American Phytopathological Society, St. Paul, MN.

43. Yudin, L. S., Mitchell, W. C., and Cho, J. J. 1987. Color preference of thrips (Thysanoptera: Thripidae) with reference to aphids (Homoptera: Aphididae) and leafminers in $\mathrm{Ha}$ waiian lettuce farms. J. Econ. Entomol. $80: 51-55$ 